\title{
REVIEW
}

\section{Liberation and spread of stoats (Mustela erminea) and weasels (M. nivalis) in New Zealand, 1883-1920}

\author{
Carolyn M. King \\ Environmental Research Institute, School of Science, University of Waikato, Hamilton 3240, New Zealand \\ (Email: cmking@waikato.ac.nz)
}

Published online: 29 May 2017

\begin{abstract}
This paper reviews the timing and spread of weasels and stoats across the South and North Islands of New Zealand during the late nineteenth century, entirely from historical records. The flavour of the debates and the assumptions that led to the commissioning of private and government shipments of these animals are best appreciated from the original documents. I describe the sites of the early deliberate releases in Otago, Canterbury, Marlborough, and Wairarapa, and list contemporary observations of the subsequent dispersal of the released animals to named locations in Southland, Westland, Wellington, Hawke's Bay, Auckland and Northland. Originally, weasels were landed in far greater numbers than stoats (2622 weasels and 963 stoats listed in shipment records) and, while at first they were very abundant, they are now much less abundant than stoats. Two non-exclusive hypotheses could explain this historic change: (1) depletion of supplies of their preferred small prey including birds, mice, roosting bats, lizards, frogs and invertebrates, and (2) competition with stoats. Contemporary historic written observations on the first impacts of the arrivals of weasels and stoats on the native fauna offer graphic illustrations of what has been lost, but usually failed to consider the previous impacts of the abundant rats (Rattus exulans since the late 13th century, and R. norvegicus since 1770s-90s), and cannot now be distinguished from the activities of $R$. rattus arriving in the $1860 \mathrm{~s}-90 \mathrm{~s}$.
\end{abstract}

Keywords: dispersal; environmental history; introduced predators; liberations; mustelids

\section{Introduction}

The management of invasive predators is a complex matter, with unpredictable results (Tompkins \& Veltman 2006; Ruscoe et al. 2011), and has ethical as well as scientific dimensions frequently discussed in recent literature (Robinson et al. 2013; Russell et al. 2016). It is of course essential that the doleful history of past human misjudgements be analysed in the light of current knowledge, but that viewpoint as filtered through present day assumptions and hindsight can also introduce a new set of misjudgements. The primary values of the decisionmakers of past times, and their perceptions of 'the balance of nature' and the efficiency of 'natural enemies', were very different from ours.

Therefore, historical events are best understood from documents written soon enough after the event to be free of later reinterpretations, and read in the original words. Much as we may be, rightly, wary of newspaper journalism, the late nineteenth century newspapers were well developed and highly valued as the only source of public information, both local and international (Pawson \& Quigley 1982), and their reports were often very detailed and comprehensive. Consequently, historic news items are worth careful scrutiny, because those written by eye-witnesses, especially if citing reputable authorities or government officials, often recorded valuable contemporary observations of the natural world, illustrating how people thought and behaved in the past (King 2017c).

To understand the course of events, we must appreciate the differences between what people did then, versus what we may wish they had done, or would have done in their place. They used to accept, as simple statements of fact, bald opinions and actions that we now find incredible and reject as false or misleading, but which seemed then to be the most reasonable attitudes and the best thing to do at that time. For example, an appropriate introduction to this paper is provided by an extract from a report written in 1898 by Mr Reginald Foster, a former Chief Stock Inspector for Canterbury, and reprinted in the Matura Ensign (1898).

Tame, hutch-bred rabbits were liberated by the early settlers in many parts of the colony, and, owing to the absence of indigenous natural enemies, they soon established themselves, but it was not until the wild rabbit was introduced in Southland in 1852, and the equally wild silver grey at Kaikoura by Capt. Keene about the same year, that their increase became noticeable...the danger was not realised until the rabbit commenced to spread northwards like a tidal wave, causing inevitable ruin in their progress...[so] Government introduced stoats and weasels for liberation on the Crown lands... although I, in common with all sportsmen, regret their introduction, I am satisfied that they are, and will continue to be, the main factor in keeping the rabbit pest under [control] on the higher lands in the colony where it is impossible to deal with them effectively by any of the known means of rabbit destruction.

Foster's view of the introductions policy is determined by two unquestioned convictions, which he shared with most of his contemporaries: (1) that the most regrettable consequences of the arrival of stoats and weasels were the losses they caused to sportsmen by their predation on introduced game birds, and (2) that stoats and weasels were fully expected to be capable of 
controlling rabbit numbers. Few ecologists would now agree with either opinion, but this way of thinking was widely held at the time, and strongly influenced the nineteenth-century governments' strategy.

\section{Methods}

Official government publications - mainly the reports of Parliamentary debates and the Appendices to the Journal of the House of Representatives (AJHR) - are available both in libraries and online. Deposits of unpublished official documents are held in Archives NZ, most freely accessible to readers on site, and locatable in their catalogue www.archway.archives. govt.nz from the record number given in the reference list below. Non-government documents such as letters, farm diaries, and unpublished analyses are held in the Alexander Turnbull Library (Wellington), the Hocken Library (Dunedin), the Auckland Institute and Museum; the city libraries of Auckland and Dunedin; and the Maritime Museums of Auckland, Port Chalmers and Bluff (regrettably, the Lyttleton Maritime Museum was closed in 2011 by earthquake damage). All of these I have searched in person. In addition, professional archivists searched several smaller New Zealand museums on my behalf.

By the mid-nineteenth century there were dozens of New Zealand provincial newspapers, with regular access to the international community by telegraph, and most are now digitised and easily searchable online at https://paperspast. natlib.govt.nz. There is a comparable database for British newspapers at www.britishnewspaperarchive.co.uk. Financial records are cited in the currency New Zealand used in the nineteenth century, the British pound sterling $(£)$, divided into 20 shillings (s), each of 12 pence (d). The Reserve Bank of New Zealand provides an online calculator for converting prices back to 1862 into contemporary NZ dollars (\$) (www. rbnz.govt.nz/monetary-policy/inflation-calculator).

Stoats (Mustela erminea) and weasels (M. nivalis) are often confused, because the distinguishing black-tipped tail of the stoat is not always noticed, then or now. Most of the primary sources refer to both together, often under the general term 'weasels'. For only 15 of the 25 known shipments plus one uncertain record (King 2017b) are the two species listed separately, although there is no guarantee of correct identification. Ferrets ( $M$. furo) are quite different, in appearance, biology and origin, so their history in New Zealand is described separately (King 2017c). The generic label 'mustelids' includes all three species. Variant spellings ('weasle', 'weazel') are given as in the original sources to facilitate checking of material. Reviews of the full historic details of the trade in stoats and weasels (King in press), and of the post-invasion ecology of stoats and weasels in New Zealand (King et al. 2017) are given elsewhere.

\section{Results}

By the early 1870 s, uncontrollable increases in numbers of European rabbits were causing massive pasture damage in Southland and Marlborough (Richardson \& Pearson 1876). Feral cats (Felis catus), weka (Gallirallus australis hectori) and Australasian harrier hawks (Circus approximans) were already resident on open country, but having no apparent effect on rabbit numbers. Ferrets (Mustela furo) are semidomesticated animals, easy to breed in captivity and widely available to buy, so were the first mustelids to be released in very large numbers on rabbit-infested pastures over a long period (c. 1870s-1920s). Ferrets are well adapted to burrowhunting rabbits in grassland habitats (Clapperton \& Byrom 2005) but the mortality rate of the ferrets released was high because they are susceptible to canine distemper and cold wet winters (King 2017c).

Stoats and weasels were imported later, in smaller numbers and over a shorter period (1883-1892). Government and private imports of stoats and weasels - 'the natural enemy' from England - were seen to be the only way to curb the rabbit menace in the high country where ferrets were regarded as too 'delicate' (Bayly 1883), so as soon as each shipment arrived, stoats and weasels were transported to the worst-affected runs. The priority areas were identified in the 1886 Report of the Joint Committee on Rabbit and Sheep Acts:

...the colony is not only suffering a heavy annual loss from the very great numbers [of rabbits] still existing in infested districts, but that the infested area is constantly increasing...rabbits are making their way into...Canterbury from Amuri in the north and from the Mackenzie country in the south and west; while in the North Island they are spreading from the Waikato into the King Country and from the Wairarapa into Hawke's Bay...[we] should without delay take steps to provide for a large and constant supply of stoats and weasels (Anon. 1886).

Within 20-30 years, stoats and weasels had spread into the bush throughout both main islands. Both are small enough to be vulnerable to attack by larger predators (ferrets, cats and hawks) resident in open country. Stoats in captive experiments were observed to avoid cats and ferrets, even at the cost of going hungry (Garvey et al. 2015). However, they are good climbers, and readily find food and cover in forests (King \& Powell 2007). Hence, the present distributions of stoats and weasels bear little relationship to their original release areas.

\section{The Rabbit Nuisance Act 1881}

The Government's Chief Rabbit Inspector, Benjamin Bayly (appointed in 1881), tightened up the previous rabbit-control legislation and organised the shipments of stoats and weasels. In the hope of conserving every possible weapon against rabbits, the new Act placed all natural enemies of the rabbits under legal protection. Anyone could be fined up to $£ 10$ for killing a ferret, stoat, weasel or cat, even in areas where there were no rabbits.

Accelerating outrage and complaints from the settlers, that this illogical provision prevented them from destroying predators to protect their cherished poultry and introduced game birds, produced only a terse official notice from John McKenzie, Minister for Agriculture (New Zealand Gazette 1894), as reported by the Otago Witness (1894): 'Attention is drawn to the Provisions of "The Rabbit Nuisance Act 1882" for the protection of the natural enemy of the rabbit, and it is hereby notified that the animals mentioned hereunder have been Protected, as provided for in Section 29 of the abovementioned Act: ferrets, cats, stoats, weasles, mongoose'.

The only legal remedy then available was to remove the offending predators alive to somewhere they would be more welcome. In November 1897, a letter from the local agent of the Department of Agriculture at Hanmer reported that 'Stoats...getting very numerous on the Plains... and either stoats or weasels have started to destroy the Poultry. In a pile of wood at the Sanatorium there must be over a dozen[. W] 
ould you sanction my trying to trap them and liberate on the [hill?] country' (Multiple authors 1896-1898).

Only in 1903 did the Government allow a new clause to be inserted into the Act, providing that 'the Governor may, on a petition of the local authority or acclimatisation society, declare that weasles, stoats, or any other animal, proved to be enemies of game [birds], be killed' (Wanganui Herald 1903). Subsequent legislation is summarised by Wells (2009).

\section{Liberations of newly-arrived stoats and weasels}

At least 7838 stoats and weasels were landed in New Zealand over the decade 1883-92, in at least 25 organised shipments listed elsewhere (King 2017b). The new arrivals were liberated only on the worst rabbit-infested pastures, but both species spread rapidly, reaching most parts of the North and South Islands within $20-30$ years.

Detailed analyses of these liberation records, and of subsequent public comment if available, can be used not only to understand why this programme was pursued against vehement opposition, but also to reconstruct the pattern of spread of these alien predators, and the approximate dates of their arrival into districts far from where they were first released. The following analysis includes all consignments of stoats and weasels for which the liberation locations are known and/or the relative proportion of the two species is stated.

\section{Otago}

The first trial shipment of 25 stoats and weasels (plus 8-10 ferrets) was loaded onto the sailing ship Waitangi in December 1882 , in the care of an experienced gamekeeper from
Lincolnshire, Walter Allbones. All but ten of the animals were lost overboard during a storm (Otago Daily Times 1883); the survivors were released at Bushey or Bushy Park (sources use either name), an estate near Palmerston (Figure 1). Within a few hours one of the ten (unidentified) had travelled several miles distant from where it was set free, where it destroyed seven ducks (Otago Daily Times 1884).

Allbones was immediately commissioned by the government to bring another lot, this time on the Doric, one of the first steam ships to be employed on the direct passenger route from Britain. The Doric and other early steamers made possible a long series of successful consignments. On this voyage, 27 stoats and 74 weasels were shipped (Bayly 1885), of which 23 stoats and 67 weasels were landed safely on 28 June 1884 (Table 1), to the great delight of the Colonial Secretary (Colonial Secretary 1884). Later consignments became larger as demand grew and Allbones' confidence and experience permitted.

Bayly cautiously decided to have the new arrivals released on a peninsula in Lake Wanaka, which might limit their spread if their effects proved too damaging. Naturally, he hoped they would be successful, and would then establish a front line of natural enemies ready to check the northward march of rabbits before they reached the Canterbury boundary (Wairarapa Standard 1884). The local Rabbit Inspector Blair Fullerton reported that when the boxes were unloaded from the Doric, carted to the peninsula and opened, the 90 surviving animals ran out of them and appeared quite as lively as if they had never experienced a long sea voyage and close confinement (Mataura Ensign 1884).

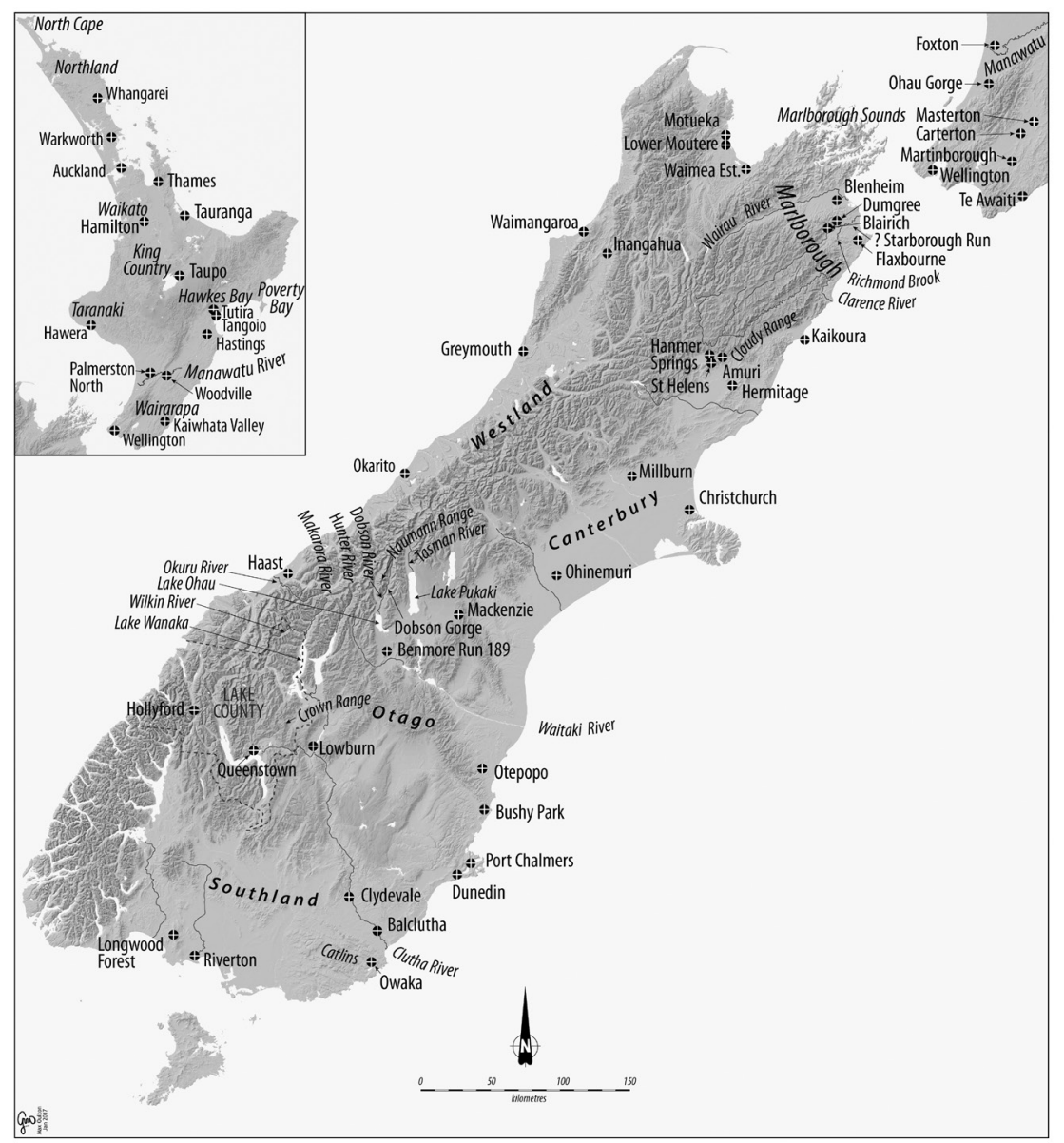

Figure 1. Locations of places mentioned in the text. Cartography by Max Oulton. 
Table 1. List of 15 named shipments of stoats and weasels imported into New Zealand, plus one record possibly referring to more than one shipment, 1884-1892. These records mentioning the species composition of successful consignments total 3585 animals, less than half the minimum estimate of 7838 stoats and weasels landed (King 2017b). In another nine shipments, and in all import records, the species were not listed separately. Dates of arrival at the first port of call in New Zealand taken from the Comber Index until it ends in 1889 (Comber Index 1985). Numbers of animals are approximate, and sources do not always agree. Abbreviations: S: Sent. L: Landed. WA: Walter Allbones. HA: Henry Allbones (Walter's father). GS: George Storey.

\begin{tabular}{|c|c|c|c|c|c|c|c|}
\hline \multirow{2}{*}{$\begin{array}{l}\text { Date arr } \\
\text { NZ }\end{array}$} & \multirow{2}{*}{$\begin{array}{l}\text { Ship and } \\
\text { courier }\end{array}$} & \multicolumn{2}{|c|}{ Stoats } & \multicolumn{2}{|c|}{ Weasels } & \multirow[t]{2}{*}{ Distributed to } & \multirow[t]{2}{*}{ Reference } \\
\hline & & $\mathrm{S}$ & $\mathrm{L}$ & $\mathrm{S}$ & $\mathrm{L}$ & & \\
\hline 1884.6.28 & Doric, WA & 27 & 23 & 74 & 67 & Otago & (Bayly 1885) \\
\hline 1885.1 .20 & Ionic, WA & 33 & 32 & 128 & 116 & $\begin{array}{l}\text { Marlborough, } \\
\text { Wairarapa, Otago }\end{array}$ & (Bayly 1885; Pinney Unpublished-b) \\
\hline 1885.7 .12 & Rimutaka, HA & 55 & 55 & 181 & 167 & Wairarapa & $\begin{array}{l}\text { (Colonial Secretary } 1885 \text {; Colonial Secretary \& } \\
\text { Riddiford 1885) }\end{array}$ \\
\hline 1885.10 .28 & Ionic & 89 & 82 & 196 & 167 & Otago & (Colonial Secretary 1885; Bayly 1886) \\
\hline 1888.1 .5 & Tongariro, HA & & 56 & & 229 & Marlborough & (Marlborough Express 1888c) \\
\hline 1888.4.23 & Kaikoura, HA & & 94 & & 225 & $\begin{array}{l}\text { Clarence, } \\
\text { Canterbury/Otago } \\
\text { boundary }\end{array}$ & (Bayly 1888) \\
\hline 1888.7 .3 & Ionic, GS & 39 & 38 & 273 & 257 & $\begin{array}{l}\text { Marlborough, } \\
\text { Otago }\end{array}$ & (Chief Inspector of Stock in Sydney 1890) \\
\hline 1888.8.12 & Ruapehu, HA & 128 & 120 & 208 & 192 & Marlborough & (Chief Inspector of Stock in Sydney 1890) \\
\hline 1889.8 .13 & Aorangi, HA & & 45 & & 182 & Marlborough & (Marlbough Express 1890) \\
\hline 1891.1 .30 & Tongariro & 150 & & 224 & & Wairarapa & $\begin{array}{l}\text { Wairarapa Daily Times (1891a) says only } 42 \\
\text { survived, of which the species were not } \\
\text { distinguished }\end{array}$ \\
\hline 1891.2.26 & Aorangi & 98 & 13 & 28 & 0 & South Island & (North Otago Times 1891) \\
\hline 1891.2.12 & Rimutaka & 120 & & 236 & & Wairarapa & (Evening Post 1891b) \\
\hline 1891.4.21 & Ruapehu & 117 & 85 & 228 & 165 & Wairarapa & (Fielding Star 1891) \\
\hline 1891.5.? & Kaikoura & 104 & & 428 & & Wairarapa & (Wairarapa Daily Times 1891c) \\
\hline 1891.7.16 & Aorangi & 91 & 83 & 258 & 245 & Wairarapa & (Wairarapa Daily Times 1891b) \\
\hline 1891-92 & $?$ & & 237 & & 610 & Wellington & (Ritchie 1892) \\
\hline Totals & & 1051 & 963 & 2462 & 2622 & & \\
\hline
\end{tabular}

The next shipment of 32 stoats and 116 weasels arrived on the Ionic, on 20 January 1885, out of 33 stoats and 128 weasels shipped (Bayly 1885). The demand from landholders required Bayly to distribute the animals in much smaller lots than needed to maximise their chances of establishment. For example, only 30 weasels and eight stoats were taken to Queenstown for C.C. Boyes on 6 February 1885 (Lake Wakatip Mail 1885). Hon. Robert Campbell managed to score seven stoats and 25 weasels for his Benmore run via his Dunedin agent, A. C. Begg (Pinney Unpublished-a, b). The archives of the New Zealand Loan \& Mercantile Agency Co, Ltd in Dunedin include an entry ' 3 February 1885 'To stoats and weasels £90-05-00: Robert Campbell \& Sons, Ltd. A.C. Begg, Dunedin' (P. Holland, pers. comm. 2016).

Campbell's manager Thomas Middleton reported to him, on 13 February 1885 , that he had turned them out "where rabbits bolted under rocks, and they started work at once. We could hear the rabbits singing out. While we were watching them, a young weka rushed out from under a rock with a weasel hanging on, but it fell off with a mouthful of feathers'. Ten days later, in a letter to John Wilson, Campbell's agent in London, Middleton marvelled that 'The little things seemed none the worse for their journey, but ran away and disappeared at once among the rocks - going for the rabbits and wekas minutes afterwards'. He added on 21 March that he 'visited the weasel locality, no rabbits to be seen' (Pinney Unpublished-b).

These reports induced some envy on neighbouring properties. Other landholders in Queenstown were quick to request an allocation from the next government shipment due in October 1885 (Miller 1885). Campbell's neighbour William Stronach of the Lake Ohau run in the upper Waitaki, who got nothing from the Ionic's January consignment, pleaded to be allocated some: '[I hear that] the stoats and weasels were doing good work when you had them turned out in Otago... they are the best enemy of the rabbit we can get...' (Multiple authors 1885).

Half the Ionic's January shipment was auctioned off: 'Six stoats realised $£ 52 \mathrm{~s} 6 \mathrm{~d}$ each, and 20 weasles $£ 310$ s each. The estimated cost to the Government was about $£ 25$ s per head all round. The remainder of the shipment [other than those sold to private landowners in the Wairarapa and Marlborough] are to be turned loose in the back-country of Canterbury and Otago' (Otago Daily Times 1885). Not everyone got as many animals as they wanted, or even any at all: Bayly told the disgruntled landowners that 'there were so many applications that if I had had ten times the number I could have disposed of them' (Randall Johnson 1884).

In October 1885, the Ionic was back with a Government shipment of 82 stoats and 167 weasels (Colonial Secretary 1885). Bayly (1886) reported that these animals were distributed in 'equal parts to (1) the Wilkin River valley, (2) the east side of the Makarora River, (3) the Naumann Range, and (4) the Waitaki River valley', although he lists the numbers as 82 stoats and 126 weasels.

Kaikoura's load of 319 animals, which arrived on 23 April 1888 , included a substantial consignment for the boundary 
country between Canterbury and Otago. The wording is somewhat unclear, but implies that these were the 'over two hundred stoats and weasels [that] have been released near the Hermitage, Pukaki Lake, Ohau and Dobson Gorges, and Naumann Range' mentioned by Bayly (1888). The annual report to the Rabbit Nuisance Committee dated 18 May 1889 acknowledged liberations totalling about 789 stoats and weasels around Lake Ohau and between Ohau, Pukaki and Tasman River (Anon. 1889). Clydevale, in the Clutha valley, received 81 from the Ionic in July 1888 (Clutha Leader 1888) and 130 in 1889 (Anon. 1889). Weasels were reported to have reached Millburn, between Balclutha and Dunedin, by July 1890, supposedly having come 'from the South' (Otago Witness 1890b).

By 1892, Blair Fullerton, the Rabbit Inspector based in Oamaru, found that 'Weasels are spreading throughout the Clutha... and evidently are increasing rapidly'. He added that it would be some time before they would be numerous enough to keep down the rabbit pest, as they have mice, rats, and birds to eat as well as rabbits (Ritchie 1892).

In 1893, Mr J. D. Ritchie, Secretary for Agriculture and Chief Inspector of Stock, conducted a survey of the opinions of all his district sheep inspectors concerning the current distributions of stoats and weasels. Their responses are given as a series of statements in his annual report (Ritchie 1893). The Otago section states that weasels were often seen in the Dunedin district, and occasionally trapped. In the Lakes district they were spreading everywhere; weasels were very plentiful around Wanaka and 'up the Hunter'. Around Balclutha, weasels were increasing very much, especially in the Catlins and Owaka districts, and 'doing good'.

By 1901 the Otago Acclimatisation Society was in despair. 'It is no use trying to establish game birds [in] our district, so long as the rabbits are with us. Ferrets and weasles are numerous everywhere, and are increasing in numbers every year' (Evening Star 1901). In another 2 years they were 'very numerous on the Crown Range' (Lake County Press 1903). By July 1908, 'Stoats and weasles are very plentiful now-a-days...the day will come when they will be ranked as the worst vermin in the country' (Clutha Leader 1908). In the Tuapeka district, on the hills to the west of Otepopo [near Waianakurua], stoats were reported in large numbers along the hills, outnumbering the weasles, and 'will almost dispute the right of way with a human being' (Tuapeka Times 1909).

Stoats and weasels rapidly became more numerous in the Waitaki Valley, introducing a conflict of interest between station owners and managers on the one hand, and the men employed to control rabbits by traditional trapping methods on the other. James Sutherland, by then the manager of the Benmore run, reported with regret in April 1907 (Pinney unpublished-c) that stoats and weasels were often caught in traps set for rabbits, but that rabbit trappers regarded them as enemies threatening their means of living, so killed every stoat and weasel they could - ignoring their legal protection. The trappers' antipathy is understandable from their point of view: one setting of 20 rabbit traps near Lowburn collected 11 weasels and three rabbits (Cromwell Argus 1916).

\section{Canterbury}

Many of the early releases were deliberately concentrated on the borders of southern Canterbury, in the hope of slowing the march of rabbits northward from Otago. The 1889 annual report to the Rabbit Nuisance Committee includes a statement from R. Foster, the district sheep inspector based in Christchurch, that a total of 600 stoats and weasels were liberated in the district during the year (Anon. 1889). Ritchie's survey found that both stoats and weasels were rapidly increasing at the head of Lake Ohau, and between Ohau and the Tasman River (Ritchie 1893).

\section{Marlborough-Nelson}

Rather few stoats and weasels had been sent to the Marlborough runs before the mid-1880s, because run holders there were especially keen on ferrets, and had been breeding and releasing them by the thousand (King 2017c). Stoats could not be locally bred, so the supply was limited to the number that could be imported from England in shipments of a few hundred at a time, and once landed they were much more expensive to buy than ferrets. L. W. McCaskill of Molesworth Station mentions that, in $1886 \mathrm{~W}$. Low of St Helens paid $£ 5$ a head for six stoats for the lower Acheron valley, compared with the $£ 1$ a head paid for ferrets by Sir N. Campbell for the Cloudy Range run (McCaskill 1969, p. 150).

Only part of the Ionic's January 1885 shipment of stoats and weasels had been purchased for the northern South Island, but by 1888 the Awatere Rabbit Board was turning to more concentrated importations of stoats and weasels as a key weapon against rabbits. They worked through Holmes \& Bell, a firm of stock and station agents with offices in Blenheim and in London, who supplied mustelids to the Board until 1891 (Marlborough Express 1891). In January 1888, the Board received notice that 255 stoats and weasels had just arrived [misprinted for 285; Table 1], the first instalment of an ambitious order for 1000 animals, to be divided between the station owners of the Awatere district in the proportion of one stoat or weasel to 2000 sheep (NZ Herald 1888). They were accompanied on the Tongariro from England by Henry Allbones (Passenger records $1885-90) ; 56$ stoats and 229 weasels were transferred to the coastal steamer Penguin for the final passage to Picton (Marlborough Express 1888c).

Later instalments of the Awatere Rabbit Board's massive order arrived over the next 18 months. Twenty animals from the Kaikoura arriving on 23 April 1888 were sent to the Clarence River (Bayly 1888), followed by another 197 from the Ionic arriving on 3 July 1888 and 74 from the Ruapehu on the 17th (Marlborough Express 1888b; Chief Inspector of Stock in Sydney 1890).

The Marlborough Express summarised the total number of animals imported by the Awatere Rabbit Board up to 24 July 1888 as 917 stoats and weasels, of which there were two escapes, 12 lost on tally, and 108 died on voyage, out of 1055 animals sent in three shipments (Marlborough Express 1888b). Under instructions from Messrs Goulter and Vavasour, both Awatere Rabbit Board members, consignments were delivered to the Dumgree, Starborough, Richmond Brook, and Blairich Stations on 15 July, at an average cost of $£ 37 \mathrm{~s}$ a head(Marlborough Express 1888a). The same report mentions two otherwise unknown additional shipments on the Rimutaka and the Amuri.

In February 1889, the Awatere Rabbit Board placed another order for $£ 1200$ worth of stoats and weasels, to be landed in Blenheim in September or October 1889. The first of these are probably the 250 dispatched with Henry Allbones on the Aorangi on August 13th, of which 227 arrived (Marlborough Express 1889), although the destinations of the animals are not stated. Holmes \& Bell reported to the Board that Allbones had been the first to bring these animals to New Zealand, and that 'this completes his 17 th shipment'. 
The annual report to the Rabbit Nuisance Committee dated 18 May 1889 mentions that 1000 stoats and weasels had been liberated by the Awatere Rabbit Board during the year (Anon. 1889) and the following year's report added another 1081 (Anon. 1890). By March 1890, 'weasles had been found in the Waimeo [sic: Waimea in Fig. 1]. The nearest point where any were liberated is Birch Hill, the opposite side of the Wairau River' (Oamaru Mail 1890).

When the next shipment arrived, on the Tongariro on 9May 1890, the Board decided that the Clarence River-Flaxbourne country should get $£ 100$ worth of stoats and weasels above its share from this shipment, to make up for past deficit. By December 1891, weasels were reported to have spread to Lower Moutere (near Motueka) (Colonist 1891).

Ritchie's 1893 survey found that large numbers of stoats and weasels had drifted into the Marlborough Sounds country, which was unfortunate as settlers there had no rabbits and little sympathy for the 'natural enemy' that was brought in to save the inland run holders. Rather, the Sounds settlers destroyed stoats and weasels whenever possible, to protect their poultry (Ritchie 1893). By contrast, the same source reported that natural enemies were well established and very numerous on the sheep runs of the Amuri-Kaikoura district, especially weasels, and were, according to observers of the time, largely responsible for the satisfactory condition of the district (i.e. few rabbits).

\section{Wairarapa}

Part of the shipment that arrived on the Ionic on 20 January 1885 was purchased for the Wairarapa area, probably around Carterton. Edward J. Riddiford, a prominent Wellington politician and run holder of the southern North Island, then commissioned Allbones to bring out two private shipments for his own estates. The first one arrived on the Rimutaka in Wellington on 12 July 1885 (Table 1). Henry Allbones accompanied the animals ( 167 weasels and 55 stoats) (Colonial Secretary 1885) from the harbour to Martinborough, the nearest inland town to Riddiford's Te Awaiti station on the rugged hills of the Wairarapa east coast.

The diary kept by the station manager of the Te Awaiti run records that on $15 \mathrm{July}$, two men rode to Martinborough with packhorses, returning on the 16th with 69 boxes of stoats and weasels (Winser 1885). The diary then lists the distribution of the boxes by packhorse around the station each day between the 17th and 21st of July (Fig. 2). According to Grant (1883), each box held three animals, presumably separated by internal partitions. Both Henry Allbones and Riddiford were present at the station throughout the operation, and they took the opportunity to negotiate a new contract for a second shipment, dated 14 July 1885 (Riddiford 1885). Copies of the handwritten contract for the second shipment survive in the private collection of Walter's grandson David, who still lives on the family property in Brigg, Lincolnshire.

Riddiford's first shipment had been organised through the Colonial Secretary's office and the Agent General in London. The Agent General charged $£ 67413$ s $4 d$ for collecting the animals in England and organising their transport and feeding on the voyage, on top of which the Colonial Secretary added wages for Allbones and his assistant plus the Government bonus of $5 \mathrm{~s}$ for every weasel and $7 \mathrm{~s}$ for every stoat landed alive. The total came to $£ 80316 \mathrm{~s} 8 \mathrm{~d}$, an enormous sum. Hardly surprising, then, that the Colonial Secretary had to remind Riddiford, several times, to pay it (Colonial Secretary \& Riddiford 1885).

The second shipment of animals for Riddiford (species not specified) arrived on the Rimutaka on 6 November 1885 . The
Te Awaiti station diary is completely blank for November and December that year. But more than 2 months later, Riddiford's personal diary records that on 25 January, he 'went to the Loan Co. the stoats and weasels would not sell' (Riddiford 1886). The clear implication is that Riddiford, hard pressed by the Colonial Secretary to pay his previous bill, held back from distributing the second lot of animals while he attempted to raise funds by selling them to other parties. The idea seems to have failed, because on 27 January 1886 the manager of Riddiford's Te Awaiti station recorded that he and Caverhill (one of his men) 'went to Waipawa to meet weasels' (Winser 1886). The station diary notes the distribution of the animals around the run over the next 4 days (Fig. 3), in what must have been miserable conditions of steady rain until the 31 st.

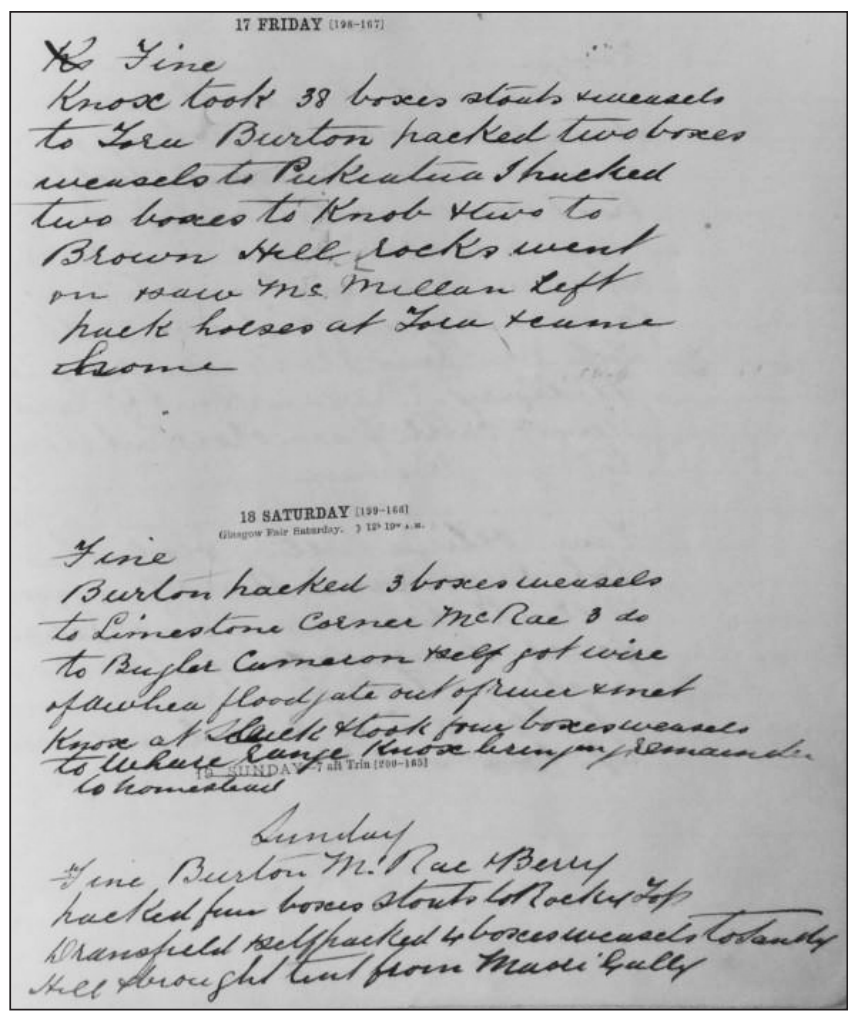

Figure 2. Extract from the Te Awaiti station diary documenting the distribution of stoats and weasels around the property in July 1885 (Winser 1885). For translation, see Appendix 1.

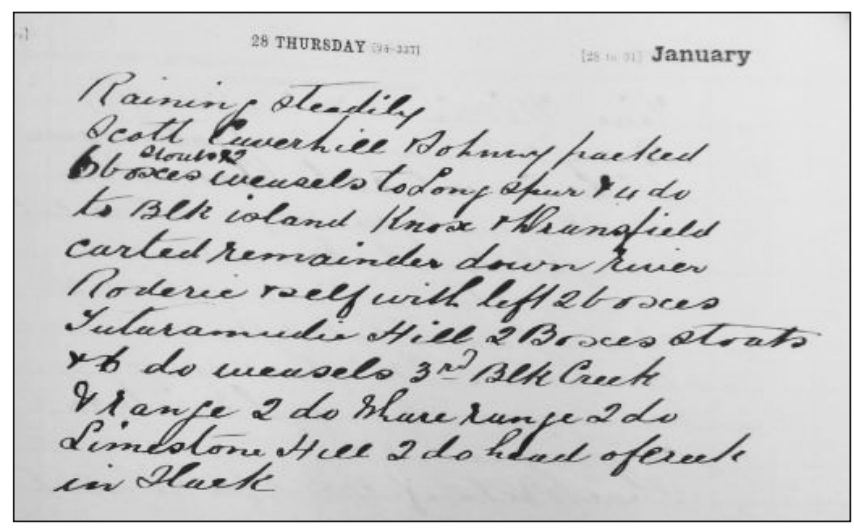

Figure 3. Extract from the TeAwaiti station diary documenting the distribution of stoats and weasels around the property in January 1886 (Winser 1886). See Appendix 1. 
Eventually, Riddiford must have been pleased with his investment at Te Awaiti, because less than 2 years later, Bayly's 1887 annual report included a statement from the local rabbit inspector, that: 'Stoats and weasels are spreading over the district; 300 were recently turned out on Te Awaiti by Riddiford, with excellent results'(Bayly 1887). The 1889 annual report of the Joint Committee on Livestock and Rabbits (Acland 1889) states that stoats and weasels have been seen 30-40 miles away from where they were released by Riddiford.

In 1890, 5 years after the releases, C. R. Caverhill, Riddiford's then manager, stated that: 'I am of the opinion that these animals have done good work since Mr Riddiford turned them out between four and five years ago; but of course the number was small considering the extent of the country they were distributed over... [proof that] the weasels are doing good is the small number of young rabbits seen on the place... The rabbiters also tell me that they get very few does in full milk, but a great number have the appearance of having lost their young' (Hawke's Bay Herald 1890).

Caverhill's report suggests that, assuming other conditions remained similar, the arrival of the mustelids had had a real effect on the adult fertility rate, parturition success and juvenile survival of rabbits. Since these parameters are important levers of change in rabbit population dynamics (Thompson \& King 1994; Norbury \& Reddiex 2005), this is more persuasive evidence of an impact than simple changes in rabbit numbers, which could have had several other explanations.

\section{Wellington, Manawatu and Taranaki}

Riddiford's success no doubt encouraged more shipments for the lower North Island over the following few years. In November 1888 , the Ionic brought 'a hundred stoats and weasels for Wellington'(Otago Daily Times 1888), although the source does not say which species or where they were released. In 1890 the Rabbit Nuisance Committee's annual report commented that a stoat had lately been found on the west side of the Manawatu River where none had been turned out (Anon. 1890). Within another 2 years an incursion of stoats and weasles into the Manawatu district was beginning to cause anxiety, and young poultry were fast disappearing from several farmyards in and near the vicinity of Palmerston North (Evening Post 1891a).

In April 1891, a shipment of 165 weasles and 85 stoats from the Ruapehu was delivered in Masterton for the North Wairarapa Rabbit Board (Fielding Star 1891). The following year, John Drummond, the sheep inspector for the WellingtonWest Coast district, reported to the Rabbit Nuisance Committee that, in addition to the number of natural enemies previously reported, 237 stoats, 610 weasels and 699 ferrets had been imported into the district, and will 'prove of immense service in controlling the pest' (Ritchie 1892).

Ritchie's 1893 survey found that both stoats and weasels had moved to the bush districts, and had travelled through to Woodville and Palmerston North where they were frequently seen. On the western side of the North Island they were found as far north as Hawera, and in the Manawatu were becoming quite numerous. A rabbiter at Foxton set fire to a flax bush and seven weasels ran out (Ritchie 1893). By 1899, stoats and weasles were reported to be exceptionally numerous in the Kaiwhata Valley [55 km north of Te Awaiti] (Wairarapa Daily Times 1899). Weasels were reported to be in Taranaki in 1906 (Tuapeka Times 1906).

Ritchie's 1893 survey includes reports from stock inspectors from all the other administrative districts, but none of them mentions mustelids at all (Ritchie 1893).

\section{Natural spread of stoats and weasels beyond the liberation areas}

\section{Southland}

The rabbit plague that devastated the southern South Island from the early 1870 s started in coastal Southland, so, understandably, the first serious proposals to introduce weasels to kill rabbits began in Invercargill in 1876 (Reading Mercury 1876). A leading Southland run-holder, Cuthbert Cowan, had ordered some weasels that 'were to have been dispatched in July' [1876] (Hodgkinson 1876). The records are vague and the numbers probably small, and there is no evidence that this or any of several other early liberation attempts managed to establish a resident population during the 1870s. In 1884, Cowan reported having received and released three weasels, but nothing had been seen of them since (Randall Johnson 1884). Only after another decade did an unofficial report in the local paper claim that 'weasles are greatly on the increase in the Riverton district' (Bruce Herald 1894).

By 1901 weasels were 'very plentiful in the Waiau district, and may often be seen in groups of two and three sporting in the grass' (Otautau Standard 1901). Within another 2 years, correspondents were remarking on 'the steady increase of the natural enemies of the rabbit. Ferrets and weasles are especially plentiful everywhere, despite the efforts of the trappers to reduce their numbers... [they do this because] exports of frozen rabbits from Southland have been gradually decreasing' (Hawera \& Normanby Star 1903).

Ironically, by the early 1900 s the relationship between people and rabbit predators had turned full circle. Rabbit-killing mustelids were no longer the New Zealand farmers' friend, but were again competing with trappers for rabbits to turn into human profits, as in the warrenning districts of England where most of the original shipments of stoats and weasels came from (King 2017b). The difference between the two countries is mainly that, at least in the nineteenth century, New Zealand still supported extensive forests filled with easier prey than rabbits. A 1912 report noted sadly that 'The Longwood forest (Southland) is infested with stoats and weasles, and it will only be a matter of a few years before the native birds are extinct in that locality' (Auckland Star 1912). Unlike some contemporary opinions, this one was all too correct.

\section{Westland}

No weasels, stoats or ferrets were deliberately released in Westland, where rabbits were few and run holders absent. But by the late 1880 s, explorers and surveyors working in south Westland began to observe 'the invasion of stoats, weazels, etc. from Otago, which had first driven the rabbit plague over the mountain to our side and then followed, and now finding the birds more attractive than the rabbits, are leaving them to multiply and meanwhile destroying ... the birds the kiwi, etc.' (West Coast Times 1890). Alfred Douglas reported on 8 May 1890 that 'several of those (or their progeny) which were turned out at Lake Wanaka some five years ago have lately been seen in various [Westland] places, one... at the mouth of the Okuru River' (Anon. 1890).

By mid-1892, weasels were reported to have crossed the ranges of the northern South Island, westward from Marlborough. The Inangahua Times reprinted a report 'from the Westport Star [that] shows how far the weasels, which were stupidly introduced into New Zealand a few years ago, have spread over the country. We received a peculiar contribution to-day in the shape of a dead weasel, caught, when alive, by 
Mr Griffiths' cat at Waimangaroa. Where the little animal came from is a puzzle. The nearest part of the island where weasles are running, is the Marlborough country' (Inangahua Times 1892). Six months later came a report of a weasel caught on a farm near Greymouth (Grey River Argus 1893).

In 1908, Jas. Donovan of Okarito set out his observations on the timing and consequences of the arrival of stoats and weasels in Westland.

[Some] blame the cutting down of our forests to a great extent as the cause of the disappearance of our native birds. This no doubt to a great extent does help to destroy them, but from my observations, extending over 25 years, I feel sure that the real cause is the stoats and weasels... [In Westland] there are no tourists or sportsmen or others destroying the birds; neither are there timber mills or bush felled for settlement sufficient to have any marked effect on their numbers; yet 25, or even 12, years ago Maori hens [weka], kiwis, kakapo, crows [South Island kōkako], and kakas were so plentiful that they could be heard everywhere or caught in thousands...I know parts of the district that were literally alive with them, but about 14 years ago [1894] we first saw the stoats and weasels, which seemed to [have] come up from the Haast and worked north right through Westland. Now those pests are through the bush everywhere, and you can ride for days along the roads, and travel anywhere through the forests where there has been no man to disturb the solitude, and you will not see or hear one of those birds (Otago Daily Times 1908).

Alas, the story is not so simple: Donovan forgot about the rats.

\section{Hawke's Bay}

Ritchie's 1893 official report states that rabbits were widespread in Hawke's Bay, but were being kept down by an effective Rabbit Board; it does not mention mustelids. However, within a year the rabbits reached Taupo, followed by their natural enemies. The settlers complained bitterly about 'the ravages of stoats and weasles, which have now made their appearance in that district' (Woodville Examiner 1894).

In Hastings in 1896, 'Weasles are reported to be playing havoc with chickens and ducks .... Perhaps they have given the rabbits up as a bad job, and gone in for something easier' (Hastings Standard 1896).

Northern Hawke's Bay was invaded by weasels moving up from the Wairarapa and Hastings in the south. Weasels thrived in great numbers; their northern migration is vividly described by Guthrie-Smith.

By 1901 [they] had reached Tangoio [on the coast north of Napier], by 1902 a specimen had been seen on Tutira... For a short period weasels overran like fire the east coast between Tutira and Poverty Bay, and then like fire died out...Nowadays on Tutira I do not hear from shepherds or fencers of the weasel once in six years. There is something ridiculous in the fact that the weasel should have arrived at the station before the rabbit, and that later, when rabbits had become numerous, weasels should have practically passed out of the district - that the cure, in fact, should have preceded the disease (Guthrie-Smith 1969, p. 354-355).

[Weasels] passed through the district and disappeared... none of any age, young or old, remained. The three years' irruption of weasels through Tutira...resembled the progress of a comet through the heavens...the invasion rolled itself up like a scroll; it came and went like a thunderstorm;...then it rained weasels; they poured along the roads... [now] the weasel is a thing of the past, and [has] remained so for many years (Guthrie-Smith 1969, p. 389).

Weasels are now by far the least widespread of the three mustelids in New Zealand, and are seldom common anywhere (King et al. 2017). Assuming that Guthrie-Smith, a careful and observant naturalist, knew the difference between weasels and stoats, the puzzle now is to explain why weasels once invaded Tutira in such unprecedented numbers, and then simply disappeared.

\section{Auckland}

Ritchie's 1893 official report mentions few rabbits and no mustelids in the Auckland district, but by 1896 the Waikato people bringing in rabbit skins for sale reported that weasels were spreading rapidly in the King Country (Telegraphic News 1896). A weasel or stoat was reported to have attacked a boy in Judges Bay, Auckland, in 1899 (Thames Star 1899), and by the next year 'The weazel may now be regarded as established right up to the suburbs of Auckland, and is making sad raids into the poultry yards, to the annoyance and disgust of thrifty housewives' (Otago Daily Times 1900), and it was 'apparently spreading towards the Ohinemuri district' [in the hills $<5 \mathrm{~km}$ SE of Paeroa] (New Zealand Herald 1900). The Rodney Agricultural Society drew attention to the rapid spread of weasles in the Warkworth district (Rodney and Otamatea Times 1901).

\section{Northland}

In Parliament, the Government had to defend itself against a claim from a Mr. Monk, on behalf of a prominent agricultural association, that it should subsidise the efforts of the settlers to counter 'the rapid increase of stoats and weasles in the north of Auckland'. The Government pointed out that it had never introduced weasels to that part of the colony. Mr. Monk replied that they had introduced them elsewhere, and they had run to the North Cape (New Zealand Herald 1901).

Weasels reached Whangarei by mid-1903. 'I regret to say', wrote a correspondent to the Northern Advocate (1903), 'that weasels have made their appearance in the settlement. It is rather rough on us, as we have not even bunny here as an excuse for their presence and I suppose we must make up our minds to lose our poultry and pheasants'.

Rats had already been raiding Northland poultry and pheasant pens for many years past, and weasels and stoats no doubt added to this predatory toll, but why did some observers immediately blame the newcomers for damage that was not, in fact new? Part of the reason could be that weasels and stoats are obviously predatory and active by day, whereas rats are strictly nocturnal, lack canine teeth and were assumed to be gnawers of stored food rather than predators of birds. Ferrets can in this case be discounted, since they did not reach Northland until the 1960s (Clapperton \& Byrom 2005).

\section{Ratio of stoats to weasels}

Most records treated the two species of small mustelids together, in part because they are often confused by casual observers. British stoats are much more capable of killing rabbits than are weasels (McDonald et al. 2000), a difference recognised by Henry Allbones in the purchase price he offered when collecting both species from trappers in England. But in the 15 of 25 known shipments for which the species were listed 
separately, nearly three times more weasels than stoats were landed (Table 1). If correct, that ratio would be understandable, because weasels were and are much more abundant than stoats on lowland English farmland, so were more likely to be caught in traps set for both (McDonald \& Murphy 2000; King \& Powell 2007). Only towards the end of the story did New Zealand importers specify a preference for stoats (Bury \& Norwich Post 1890).

Since the average of all shipments was strongly biased towards weasels, and after release they were at first reported to be more abundant than stoats, how is it that, in most broadscale predator control programmes of the recent past, catches of weasels have been vastly outnumbered by stoats? The ratio of catches varies with habitat, region and other conditions, but a few examples show the trend (Table 2, rows 1-6). If the reported numbers of each species arriving were usually more-or-less correct (a large if), there seems to have been a substantial historic change in the proportional abundance of the two species since the nineteenth century. Two possible explanations operating at different geographic scales can be proposed.

(1) In their native environments in the northern hemisphere, weasels evolved as specialist predators of small mammals averaging $<50 \mathrm{~g}$ body weight (voles (Arvicolinae), mice (Muridae) and shrews (Soricidae)). Only one such species is present in New Zealand, the wild house mouse (Mus musculus), and then rarely in any numbers except during a temporary pulse in resources. But in the nineteenth century, the New Zealand landscape offered many acceptable substitutes for small mammals, including small birds, bats, lizards, frogs, weta (Orthoptera) and other large invertebrates. One man observed a weasel rearing a family of nestlings in a rat hole, and watched her carrying food to them every day: 'it was simply lizards every time' (Southland Times 1917). While such unsuspecting small prey were abundant and widespread on the mainland, weasels could increase in numbers very rapidly. Well-fed adult female weasels can produce a second, summer litter, and female young can breed in the year of their birth, which allows a very high population rate of increase (King $\&$ Powell 2007). The high nutritive requirements of female weasels (they need to eat about a third of their body weight every day, more when pregnant or lactating) could have been easy to meet at first, and could explain the early reports of huge numbers of weasels seen in areas where they are now rare, as well as the early optimistic reports of their effects on rabbits (Bayly 1885).

In modern New Zealand, the distribution and local abundance of small prey is drastically reduced compared with the nineteenth century. The resources offered by most New Zealand habitats are now marginal for the thin and energyhungry weasel body (King et al. 2017), because they are insufficient to support more than a fraction of its reproductive potential. Weasels still eat lizards, eggs, birds and very young rabbits if available, and can respond quickly to a local irruption of mice (King et al. 1996), but in general, the absence of voles and woodmice (Apodemus sylvaticus) here means that potential prey in the range of body sizes preferred by weasels are now at best scarce and patchy in New Zealand. By contrast, stoats can take prey of larger body size (ship rats, possums, and rabbits) as well as smaller prey when available (Murphy et al. 2008). Hence, one possible hypothesis for why weasels have become generally less abundant than stoats in New Zealand is that the relative numbers of the two species may now be correlated primarily with the present distribution of their prey, not with the numbers originally released.

(2) An alternative but not exclusive hypothesis, first proposed by King and Moors (1979), suggests that the smallest members of a carnivore guild are always vulnerable to interference competition from the larger members. Wherever stoats are common, weasels suffer that disadvantage; the same applies to stoats in competition with cats and ferrets (Garvey et al. 2015). Effective removals of stoats (that happened for different reasons) in England (Sumption \& Flowerdew 1985) and Belarus (Sidorovich \& Solovej 2007) were followed by significantly increased numbers of weasels. In New Zealand today, anecdotal reports of a similar effect are emerging in places where stoats have become less common, at least locally and temporarily, in for example kiwi sanctuaries and similar protected areas after years of stoat trapping (Table 2, rows 7-9). The data are few so far, but could in future be used to test these hypotheses and their implications for better understanding the invasion history of these two species.

Table 2. Some representative examples of the ratio of stoats to weasels caught in recent trapping operations. Compare with Table 1, showing the numbers of stoats and weasels originally imported.

\begin{tabular}{|c|c|c|c|c|c|c|}
\hline Area & Years & Habitat & Ferrets & Stoats & Weasels & Reference \\
\hline Upper Waitaki & 1997-98 & Grassland & 328 & 69 & 0 & (Keedwell \& Brown 2001) \\
\hline McRae's Flat & 2006-08 & Grassland & 423 & 242 & 42 & (Reardon et al. 2012) \\
\hline $\begin{array}{l}\text { Eglinton, Hollyford, } \\
\text { Craigieburn }\end{array}$ & $1972-81$ & Beech forest & 0 & 905 & 0 & (King 1983) \\
\hline Landsborough Valley & 1998-2009 & Beech forest & 0 & 608 & 0 & (O’Donnell \& Hoare 2012) \\
\hline Eglinton Valley & 1997-2001 & Beech forest & 30 & 841 & 16 & (Dilks et al. 2003) \\
\hline Pureora Forest & $1982-87$ & $\begin{array}{l}\text { Native and } \\
\text { pine forest }\end{array}$ & 13 & 63 & 18 & (King et al. 1996) \\
\hline Pukawa, L. Taupo & $2003-17$ & $\begin{array}{l}\text { Mixed forest, } \\
\text { pasture margin }\end{array}$ & 35 & 329 & 225 & $\begin{array}{l}\text { Pukawa Wildlife Mgmt Trust } \\
\text { unpubl. data }\end{array}$ \\
\hline Northland & $2008-14$ & $\begin{array}{l}\text { Pasture, scrub, } \\
\text { coastal forest }\end{array}$ & 0 & 613 & 1361 & $\begin{array}{l}\text { NZ Kiwi Foundation, } \\
\text { unpubl. data }\end{array}$ \\
\hline N.I. Kapiti coast & $2008-17$ & $\begin{array}{l}\text { Pasture, dunes, } \\
\text { coastal forest }\end{array}$ & 0 & 121 & 582 & Sue Blaikie BVSc, unpubl. data \\
\hline
\end{tabular}




\section{Contemporary observations of the consequences for native fauna}

It seemed self-evident to early observers that the loss of native birds from untouched standing forest, e.g. in Westland, must have been linked to the first arrival of mustelids (Timaru Herald 1890). Donovan's description of the abundance of native birds at Okarito until about 1894 was firmly linked by him (and many others) to the first time when 'we first saw the stoats and weasels... [then] the birds disappeared' (Otago Daily Times 1908). B. H. Wilmot encountered a ferret warren in the Hollyford Valley, where the weka, kiwi, and kākāpō were almost exterminated. 'In the Makarora Valley these used to be plentiful, but since the advent of the stoats and weasels they are very rare, and yet rabbiting tallies have not depreciated' (Otago Witness 1890b).

Sir Walter Buller repeatedly criticised the introductions and continued campaigning against them long after the shipments had ceased in 1892. In a paper read to the New Zealand Institute in September 1894, he described the decision to bring in stoats and weasels as 'a crime. The vermin that every farmer on the Old Country was trying to extirpate as an unmitigated evil our wise Government bought up by the hundred and imported into this country in the vain hope that [they] would change their habits and take to a rabbit diet, to the exclusion of everything else!' (Buller 1895).

The correlations pointed out by Donovan, Buller, and others certainly contained some truth, but did not allow for the less obvious damage being done by previous and contemporary new arrivals in the forest, three species of rats. One of very few contemporary writers to question the usual connection with mustelids was P. J. O'Regan, who 'remembered the time when the native thrush, the saddle-back, and the orange-wattled crow [South Island kōkako] were abundant in the Inangahua Valley, but he has seen none of these species for twenty years [since 1890]. They seemed to disappear suddenly ... before the arrival of the weasel...The forests are still standing, and the food supplies are available. What drove the birds away?' (Inangahua Times 1910).

Mr William Field, the member of the House of Representatives for Otaki, suggested an answer to O'Regan's question. He responded to a complaint from $\mathrm{Mr}$ Walter Buchanan (the Member for Wairarapa), that stoats and weasels were destroying his chickens. This Mr Buchanan considered was arrant nonsense, for which he blamed the rats, not stoats and weasels (Grey River Argus 1910).

The three species of rats that have invaded New Zealand have different characteristics and effects (King 2005). The presence of two of these rat species, for a total of up to 600 years before any mustelids arrived, confuses the simple correlations proposed by contemporary observers. First, the small kiore or Polynesian rat (Rattus exulans) had become widespread across both main islands and many offshore since they arrived with the ancestors of the Māori in about 1280AD (Wilmshurst et al.2008). Kiore were the first and only rats in the forests for at least 500 years. They were probably responsible for the disappearance of many populations of roosting bats and small birds, plus ground-dwelling frogs, lizards and large invertebrates (Atkinson 1985), although much of that damage is now recognisable only by comparing offshore islands with and without kiore (Atkinson \& Towns 2005). Because of them, and other human activities, the forest fauna encountered by the first European observers was already seriously diminished compared with the pre-human original.
In 1773, Cook's ship moored close inshore in Dusky Sound for a month, and many Norway rats ( $R$. norvegicus), ran ashore from it. Norway rats rapidly became enormously abundant, displacing kiore from the forests (Innes 2005a). Norway rats can climb, but not well (Foster et al. 2011), so for most of the next hundred years the arboreal fauna was safer than the ground fauna. In 1870, Walter Buller wrote that "this cosmopolitan pest swarms through every part of the country, and nothing escapes its voracity...the wonder rather is that any of our insessorial birds are able to rear their broods in safety. Species that nest...in situations accessible to the ravages of this little thief are found to be decreasing, while other species...continue to exist in undiminished numbers' (Buller 1871, p. 46).

In undisturbed bush at Chalky Sound in 1877, Andreas Reischek found rats 'swarming...these rats are the great enemies of birds, and any bird living or breeding near the ground has but a small chance of existing... it took five months of shooting, poisoning and trapping before they showed signs of decreasing around camp' (Reischek 1930, p. 251). Given the time of their writing and the details of their observations, both authors were probably describing Norway rats.

Finally, in the 1890 s, after kiore and Norway rats had already had, one after the other, up to 600 years to do serious damage in the South Island, ship rats, stoats and weasels arrived together. Ship rats are far more abundant, fast-breeding, devastating and widely dispersed pests than any mustelid, and have over time replaced Norway rats as New Zealand's common forest rat (King et al. 2011). Unlike Norway rats, both ship rats and stoats are agile climbers, and they rapidly extended the carnage to the forest canopy (Innes 2005b). The list of bird populations extinguished or seriously damaged by ship rats is painfully long, including on islands that no mustelids ever reached (Innes et al. 2010). The same list includes bird species that are especially vulnerable to stoats, including those with large, flightless chicks such as kiwi Apteryx spp. (McLennan et al. 1996), whio Hymenolaimus malacorhynchos (Whitehead et al. 2008) and kākā Nestor meridionalis (Wilson et al. 1998). Both ship rats and stoats have certainly contributed to further declines of native fauna, especially after mast years in beech forests (Dilks et al. 2003). Unfortunately, the historical coincidence that saw weasels, stoats and ship rats arrive in the South Island at about the same time means that the proportions of damage to be attributed to each were and are impossible to determine.

Buller continued to list many observations of birds disappearing from places where they had been common, but without getting much sympathy from the government. As a last resort, in May 1895 he wrote to the Earl of Onslow, the former Governor of New Zealand (1889-1892) who was by then retired from the top office and had returned to England. Buller no doubt enclosed a copy of his 1895 paper with his letter, appealing to Onslow to persuade the Zoological Society of London to support pressure on the Colonial Government to take rear-guard action. Onslow responded with a letter to the Zoological Society, pointing out 'how very much the process of the extinction of the wingless and other birds of New Zealand has progressed during recent years, owing to the rapid dissemination throughout the Islands of stoats and weasels ... the California quail which was introduced at some cost and had increased in enormous numbers affording excellent sport, is now hardly to be seen the birds having been destroyed on the nests by the vermin... [could] the Society make some representation...[of] the opinion of naturalists in 
this country...to the Ministry and Legislature in New Zealand... that some more vigorous steps may yet be taken to arrest the fast approaching extinction of these most interesting birds of the Antipodes?' (Earl of Onslow 1895). Alas, it was already too late for that. Nothing changed.

It would be unfair to criticise nineteenth century observers for not understanding what even the scientists of the time did not appreciate: the already well-advanced consequences for nesting birds of hundreds of years of rat damage. Stoats and weasels are active during the day when their predatory activities could be observed and easily confused with the unseen damage done at night by rats. The only way to disentangle different causes of the same effects is by double-blind reversible experiments, which were not done at the time. The grief expressed by Wilmot, Donovan, Buller, Onslow and many others was genuine, but their explanation fell into the logical trap of arguing post hoc, ergo propter hoc (after this, therefore because of this): mustelids arrived, birds have gone, therefore mustelids are the cause of their loss.

By contrast, the politicians and landholders most closely involved in the decision to import mustelids were less concerned, because they calmly expected the native fauna to disappear naturally in the face of competition from the superior products of the northern hemisphere. European zoologists from Darwin onwards assumed that most of the native fauna was already doomed (Otago Witness 1876). Even the Māori anticipated their own demise, displaced by European settlers in the same way as the kiore, which Māori hunters observed to be disappearing 'owing to the warfare carried on against it by the European [Norway] rat' (Angas 1866, p. 55-56).

There was no shortage of urgent warnings from ornithologists predicting dire consequences for native birds following the introduction of mustelids. The colonists did indeed express some regret about predation on introduced game birds, but native birds were seen as unimportant, so the warnings were ignored. 'Like everything else which is native to the place, it [native forest] seems unable to bear the advance of civilisation' concluded Samuel Grant and John Foster (1880). To the run-holders, the question of whether the dying native fauna was being damaged by European rats or stoats was irrelevant beside the urgent need to implement the only way the Colonial Government could see to save the wool industry from rabbits. Bayly dismissed his critics as representing those who had 'evidently never been south or seen the damage caused by the rabbit pest'(Multiple correspondents 1886). So the most important failures in official understanding of the time was that it misinterpreted, not only why natural enemies could not control the numbers of rabbits, but also why the native birds were disappearing.

\section{Discussion}

The story of mustelids in New Zealand can be read as a good illustration of one of the late Graeme Caughley's pithy sayings about wildlife management: 'If at first you don't succeed, you don't understand the system'. In the nineteenth century the common understanding of how to reduce the numbers of rabbits was simply to find more and better ways of killing them. In the vast areas of inaccessible back country where human action was impracticable, the Colonial Government was desperate to find a way to protect its profits from wool exports, and to prevent reinvasion by rabbits of the settled districts. Mustelids seemed ideal, since it was obvious at the time that they can kill rabbits quite efficiently, so the settlers 'reasoned from visible events to invisible processes' (Dunlap 1999, p. 73). It was much less obvious that mustelids do not have the characteristics required of a good biological control mechanism - most importantly, an unlimited ability to impose additive, rather than substitute mortality on individual pests, and reproductive and dispersal rates matching or exceeding those of the pest population. As Caughley predicted, the Colonial Secretary and his advisers could not have understood these conditions, or why mustelids were incapable of getting rid of the rabbits as they were expected to do.

New Zealand's long isolation had ensured that it supported an endemic fauna hitherto free of four-footed mammalian predators (Tennyson 2010). Native fauna were not naïve to predation, but their evolved anti-predator defences protected them only from native predatory birds and reptiles that hunted by sight during the day. Mammalian predators hunt by scent and hearing, and by night as well as by day.

Mustelids, unlike domestic cats and commensal rodents, are wild carnivores that could never have reached New Zealand without deliberate human help. The arguments both for and against their deliberate introductions to such a vulnerable country seemed, to their proponents on both sides, irresistible (King 2017c). Hence, 'Nothing in connection with the naturalisation of wild animals into New Zealand has caused so much heart-burning and controversy as the introduction of these bloodthirsty creatures' (Thomson 1922, p. 70).

Bayly was convinced that stoats and weasels were better than cats at hunting rabbits, and more resistant to cold weather and to the distemper that killed many liberated ferrets. From 1881 he pursued his belief against all objections until he lost his position as Chief Inspector in 1889 (Anon. 1889). Officially organised importations of stoats and weasels ceased after that, and private imports in about 1892-94 (King 2017b). But long before then, Bayly had succeeded in importing enough stoats and weasels to ensure both species established and spread far outside their original release areas. In 1909, Sir Joseph Ward, the New Zealand Premier, considered that they had 'spread pretty well all over the Dominion' (Waikato Argus 1909). By the early 1920s, stoats and weasels were common in nearly every part of New Zealand, and in some were 'enormously abundant' (Thomson 1922, p. 72).

New Zealand is one of the prime examples in the global literature of the need for a deep understanding of the sources and distribution history of introduced species to inform management programmes. The story of the stoats and weasels introduced here makes an important contribution to a growing international literature on the interaction of documentary and genetic evidence in understanding invasive species. Genetic modelling of living stoat populations illustrates two important principles (Veale et al. 2015), both likely to apply to other introduced species. (1) The genetic diversity in the modern descendants of the first-arriving stoats is much higher where the first and most frequent releases were made in the South Island, compared with most of the North Island where stoats spread naturally from fewer releases. (2) Genetic diversity preserved by historic introductions can contribute to the conservation of native species facing new threats in their homelands.

Ferrets were being imported into New Zealand long before stoats and weasels were, and they have generally remained on the open grasslands where they were first liberated (King et al. 2017). Along with Norway rats and cats, ferrets have contributed to many of the huge losses of the native species of open country, especially weka and other ground-nesting birds, 
frogs, lizards and large invertebrates (Norbury et al. 2013), but they cannot reach arboreal prey, so are scarce in forests. By contrast, stoats are as completely at home in trees as on the ground, and much more abundant in forests than in open country (Table 2). If the colonial authorities' failed 'natural enemy' programme had stopped at ferrets, the extinction of the buff weka (King 2017a) and many other losses among the native fauna of open grasslands would still have been inevitable. But there would have been no stoats to add yet more to the devastation of the endemic forest avifauna.

\section{Acknowledgements}

This project would have been impossible without the help of many people, especially Ken Ayers, who did much of the early archive searching both in New Zealand and in UK. Librarians: Judith Holloway (Hocken), Roger Swanson (Alexander Turnbull), Cheryl Ward (Waikato University), Emma Knowles (Otago Early Settlers Museum), Rachael Gardner and Marion Lowman (Bodleian), and staff at the libraries of the Zoological Society of London and Cambridge University. Archivists: Chris Meech (Waitaki District Archive), Katherine C'Ailceta, Donal Raethel(Archives NZ, Wellington), Kas McEntyre(Alexandra), Rebecca Smith, Sonya Johnson (Invercargill), Anne Maguire (Arrowtown), Fiona Passi (Auckland), many staff at National Archives (Kew), National Maritime Museum (Greenwich), Berkshire Record Office and Museum of English Rural Life (Reading). Information: David Allbones, Ken Ayers, Sue Blaikie, Dawn Coburn, John Dyer, Nigel Fisher, Peter Holland, Frank Leckie, Rachel Letofsky, Fay McDonald, Tessa Mills, Maxine Moerbe, Mark and Claire Strawson, Evan Tosh, and the trustees of the Pukawa Wildlife Management Trust and the NZ Kiwi Foundation. Hospitality: Daphne and Bill Lee (Dunedin), Anne Sudell, Jeff and Kate Booth (Wellington), Joan Moerbe née Allbones and Maxine Moerbe (Brigg), Wolfson College (Cambridge), Lauren Harrington (Oxford). Cartography: Max Oulton. Funding: University of Waikato RTCF Grant 2016/104615. The funder had no role in study design, data collection and analysis, decision to publish, or preparation of the manuscript. Helpful comments on drafts: Ken Ayers, Daphne Lee, Andrew Veale, and the Editors and two referees.

\section{References}

Acland JBA 1889. Report of Joint Committee on livestock and rabbits. Appendix to the Journal of the House of Representatives 1889: I-11.

Angas GF 1866. Polynesia. London, Society for Promoting Christian Knowledge. www.enzb.auckland.ac.nz/ document?wid=1542\&action=null.

Anon. 1886. Report of the Joint Committee on Rabbit and Sheep Acts. Appendix to the Journal of the House of Representatives 1886: I-05.

Anon. 1889. Annual report on the rabbit nuisance [1888/89]. Appendix to the Journal of the House of Representatives 1889: H-13.

Anon. 1890. Annual report on the rabbit nuisance [1889/90]. Appendix to the Journal of the House of Representatives 1890: H-9.

Atkinson IAE 1985. The spread of commensal species of Rattus to oceanic islands and their effects on island avifaunas.
In: Moors PJ ed. Conservation of island birds. Technical Publication No. 3. Cambridge, UK, International Council for Bird Preservation. Pp. 35-81.

Atkinson IAE, Towns DR 2005. Kiore. In: King CM ed. The handbook of New Zealand mammals. 2nd edition. Melbourne, Oxford University Press. Pp. 159-174.

Auckland Star 1912. 28 May.

Bayly BP 1883. Annual report on the rabbit nuisance [1882/83]. Appendix to the Journal of the House of Representatives 1883: H-18.

Bayly BP 1885. Annual report on the rabbit nuisance [1884/85]. Appendix to the Journal of the House of Representatives 1885: H-16.

Bayly BP 1886. Annual report on the rabbit nuisance [1885/86]. Appendix to the Journal of the House of Representatives 1886: H-19.

Bayly BP 1887. Annual report on the rabbit nuisance [1886/87]. Appendix to the Journal of the House of Representatives 1887: H-18.

Bayly BP 1888. Annual report on the rabbit nuisance [1887/88]. Appendix to the Journal of the House of Representatives 1888: H-14, H-31.

Bruce Herald 1894. 26 January.

Buller WL 1871. Further notes on the ornithology of New Zealand. Transactions of the New Zealand Institute 3: 37-56.

Buller WL 1895. Some curiosities of bird life. Transactions \& Proceedings of the New Zealand Institute 27: 134-142.

Bury and Norwich Post 1890. 18 February.

Chief Inspector of Stock in Sydney 1890. Enquiry re success and costs of importing stoats and weasels into New Zealand. Archives New Zealand R17621006, Wellington.

Clapperton BK, Byrom AE 2005. Feral ferret. In: King CM ed. The handbook of New Zealand mammals. 2nd edition. Melbourne, Oxford University Press. Pp. 294-307.

Clutha Leader 1888. 13 July.

Clutha Leader 1908. 7 July.

Colonial Secretary 1884. Letter 14 July to Agent General. Outwards Letterbook - Agent-General Archives New Zealand R20557923, Wellington.

Colonial Secretary 1885. Letter to Colonial Secretary for NSW: details and costs of importing stoats and weasels to New Zealand. Archives New Zealand R24418540, Wellington.

Colonial Secretary, Riddiford EJ 1885. Correspondence re accounts for Rimutaka shipment. Alexander Turnbull Library, RiddifordFamily Papers MS-574-006, Wellington.

Colonist 1891. 17 December.

Comber Index 1985. Shipping to New Zealand, 1839-1889. Alexander Turnbull Library, Wellington.

Cromwell Argus 1916. 15 May.

Dilks P, Willans M, Pryde M, Fraser I 2003. Large scale stoat control to protect mohua (Mohoua ochrocephala) and kaka (Nestor meridionalis) in the Eglinton Valley, Fiordland, New Zealand. New Zealand Journal of Ecology 27: 1-9.

Dunlap TR 1999. Nature and the English diaspora: environment and history in the United States, Canada, Australia and New Zealand. Cambridge, Cambridge University Press. 350 p.

Earl of Onslow 1895. Letter to P L Slater, Secretary ZSL. Zoological Society Archives, London.

Evening Post 1891a. 5 January.

Evening Post 1891b. 12 February.

Evening Star 1901. 30 May.

Fielding Star 1891. 28 April.

Foster SP, King CM, Patty B, Miller SD 2011. Tree-climbing 
capabilities of Norway and ship rats. New Zealand Journal of Zoology 38: 285-296.

Garvey PM, Glen AS, Pech RP 2015. Foraging ermine avoid risk: behavioural responses of a mesopredator to its interspecific competitors in a mammalian guild. Biological Invasions 17: 1771-1783.

Grant S 1883. Letter to Major Teschemaker. Archives New Zealand R24413234, Wellington.

Grant S, Foster JS 1880. New Zealand: a report on its agricultural conditions and prospects. G. Street, London.

Grey River Argus 1893. 10 January.

Grey River Argus 1910. 8 October.

Guthrie-Smith H 1969. Tutira. The story of a New Zealand sheep station, 4th edition. Wellington, AH \& AW Reed. 464 p.

Hastings Standard 1896. 19 November.

Hawera \& Normanby Star 1903. 25 June.

Hawke's Bay Herald 1890. 5 June.

Hodgkinson S 1876. Report of the Rabbit Nuisance Committee. Appendix to the Journal of the House of Representatives 1876: I-5.

Inangahua Times 1892. 28 June.

Inangahua Times 1910. 2 March.

Innes JG 2005a. Norway rat. In: King CM ed. The handbook of New Zealand mammals. 2nd edition. Melbourne, Oxford University Press. Pp. 174-187.

Innes JG 2005b. Ship rat. In: King CM ed. The handbook of New Zealand mammals. 2nd edition. Melbourne, Oxford University Press. Pp. 187-203.

Innes J, Kelly D, Overton J, Gillies C 2010. Predation and other factors currently limiting New Zealand forest birds. New Zealand Journal of Ecology 34: 86-114.

Keedwell RJ, Brown KP 2001. Relative abundance of mammalian predators in the upper Waitaki Basin, South Island, New Zealand. New Zealand Journal of Zoology 28: $31-38$.

King CM 1983. The relationships between beech (Nothofagus sp.) seedfall and populations of mice (Mus musculus), and the demographic and dietary responses of stoats (Mustela erminea), in three New Zealand forests. Journal of Animal Ecology 52: 141-166.

King CM ed. 2005. The handbook of New Zealand mammals. 2nd edition. Melbourne, Oxford University Press. 610 p.

King CM 2017a. Contemporary observations of predation on the buff weka (Gallirallus australis hectori) by mustelids in the South Island during the nineteenth century. Notornis 64: 52-55.

King CM 2017b. Pandora's box down-under: origins and numbers of mustelids transported to New Zealand for biological control of rabbits. Biological Invasions. DOI 10.1007/s10530-017-1392-6.

King CM 2017c. The chronology of a sad historical misjudgement: the introductions of rabbits and ferrets in nineteenth-century New Zealand. International Review of Environmental History 3:141-175.

King CM in press. The history of transportations of stoats (Mustela erminea) and weasels (M. nivalis) to New Zealand, 1883-1892. International Review of Environmental History.

King CM, Moors PJ 1979. On co-existence, foraging strategy and the biogeography of weasels and stoats (Mustela nivalis and M. erminea) in Britain. Oecologia (Berl.) 39: 129-150.

King CM, Powell RA 2007. The natural history of weasels and stoats: ecology, behavior and management. 2nd edition. New York, Oxford University Press. 446 p.
King CM, Flux M, Innes JG, Fitzgerald BM 1996. Population biology of small mammals in Pureora Forest Park: 1. Carnivores (Mustela erminea, M. furo, M. nivalis and Felis catus). New Zealand Journal of Ecology 20: 241-251.

King CM, Foster SP, Miller S 2011. Invasive European rats in Britain and New Zealand: same species, different outcomes. Journal of Zoology 285: 172-179.

King CM, Norbury G, Veale AJ 2017. Small mustelids in New Zealand: invasion ecology in a different world In: Macdonald DW, Newman C, Harrington LA eds. The biology and conservation of musteloids. Oxford, Oxford University Press. Pp. 277-298.

Lake County Press 1903. 7 May.

Lake Wakatip Mail 1885. 6 February.

McCaskill LW 1969. Molesworth. Wellington, AH \& AW Reed. 298 p.

McDonald RA, Murphy EC 2000. A comparison of the management of stoats and weasels in Great Britain and New Zealand. In: Griffiths HI ed. Mustelids in a modern world. Leiden, Backhuys Publishers. Pp. 21-40.

McDonald RA, Webbon C, Harris S 2000. The diet of stoats (Mustela erminea) and weasels (Mustela nivalis) in Great Britain. Journal of Zoology 252: 363-371.

McLennan JA, Potter MA, Robertson HA, Wake GC, Colbourne R, Dew L, Joyce L, McCann AJ, Miles J, Miller PJ, Reid J 1996. Role of predation in the decline of kiwi, Apteryx spp., in New Zealand. New Zealand Journal of Ecology 20: 27-35.

Marlborough Express 1888a. 7 August.

Marlborough Express 1888b. 24 July.

Marlborough Express 1888c. 4 January.

Marlborough Express 1889. 16 August.

Marlborough Express 1890. 9 May.

Marlborough Express 1891. 17 November.

Mataura Ensign 1884. 5 August.

Mataura Ensign 1898. 21 July.

Miller J 1885. Letter 19 October to Colonial Secretary's Office, Stock Branch, from Queenstown Rabbit Inspector. Archives New Zealand R24418510, Wellington.

Multiple authors 1885. Correspondence concerning natural enemies for Lake Ohau Station. Archives New Zealand R24418111, Wellington.

Multiple authors 1896-1898. [Complaints about natural enemies]. Archives New Zealand R1762009, Wellington.

Multiple correspondents 1886. Correspondence protesting introduction of stoats and weasels. Archives New Zealand R24456501, Wellington.

Murphy E, Maddigan F, Edwards B, Clapperton K 2008. Diet of stoats at Okarito Kiwi Sanctuary, South Westland, New Zealand. New Zealand Journal of Ecology 32: 41-45.

New Zealand Gazette 1894. Formal notice of protection under S29 of Rabbit Nuisance Act 1882 for ferrets, cats, stoats, weasels and mongooses as natural enemies of rabbit. Pp. 1552.

New Zealand Herald 1888. 10 January.

New Zealand Herald 1900. 16 June.

New Zealand Herald 1901. 15 August.

Norbury G, Reddiex B 2005. European rabbit. In: King CM ed. Handbook of New Zealand mammals. 2nd edition. Melbourne, Oxford University Press. Pp. 131-150.

Norbury G, Byrom A, Pech R, Smith J, Clarke D, Anderson $\mathrm{D}$, Forrester G 2013. Invasive mammals and habitat modification interact to generate unforeseen outcomes for indigenous fauna. Ecological Applications 23: 1707-1721. 
North Otago Times 1891. 26 February.

Northern Advocate 1903. 7 August.

Oamaru Mail 1890. 21 March.

O'Donnell CFJ, Hoare JM 2012. Quantifying the benefits of long-term integrated pest control for forest bird populations in a New Zealand temperate rainforest. New Zealand Journal of Ecology 36: 131-140.

Otago Daily Times 1883. 27 March.

Otago Daily Times 1884. 10 June.

Otago Daily Times 1885. 27 January.

Otago Daily Times 1888. 22 November.

Otago Daily Times 1900. 3 March.

Otago Daily Times 1908. 12 November.

Otago Witness 1876. 9 December.

Otago Witness 1890a. 24 July.

Otago Witness 1890b. 2 October.

Otago Witness 1894. 25 October.

Otautau Standard and Wallace County Chronicle 1901. 1 February.

Passenger records 1885-90. Card indices. Archives New Zealand, Wellington.

Pawson E, Quigley NC 1982. The circulation of information and frontier development: Canterbury 1850-1890. New Zealand Geographer 38: 65-76.

Pinney R Unpublished-a. Notebook L: extracts from Benmore Diaries, 1866-88. Hocken Library MS-3178/012, Dunedin.

Pinney R Unpublished-b. Notebook M1: extracts from Benmore Letter Books, [1877-1887]. Hocken Library MS-3178/013, Dunedin.

Pinney R unpublished-c. Notebook M2: from Benmore Letter Books (cont). Hocken Library MS-3178/014, Dunedin.

Randall Johnson G 1884. Report of the Joint Committee on Sheep and Rabbit Acts. Appendix to the Journal of the House of Representatives 1884: I-5.

Reading Mercury 1876. 28 October.

Reardon JT, Whitmore N, Holmes KM, Judd LM, Hutcheon AD, Norbury G, Mackenzie DI 2012. Predator control allows critically endangered lizards to recover on mainland New Zealand. New Zealand Journal of Ecology 36: 141-150.

Reischek A 1930. Yesterdays in Maoriland. Auckland, Wilson and Horton. 311 p.

Richardson JLC, Pearson W 1876. The rabbit nuisance in Southland. Appendix to the Journal of the House of Representatives 1876: H-10.

RiddifordE 1885. Contract with WAllbones. Private Collection of D Allbones, Brigg, Lincolnshire.

Riddiford EJ 1886. Hutt Diary. Alexander Turnbull Library, MS papers 1392-23, Wellington.

Ritchie JD 1892. Annual report on the rabbit nuisance[1891-92]. Appendix to the Journal of the House of Representatives 1892: H-19.

Ritchie JD 1893. Report of the Secretary for Agriculture and Chief Inspector of Stock. Appendix to the Journal of the House of Representatives 1893: H-21.

Robinson OJ, Fefferman NH, Lockwood JL 2013. How to effectively manage invasive predators to protect their native prey. Biological Conservation 165: 146-153.

Rodney and Otamatea Times 1901. 5 July.

Ruscoe WA, Ramsey DSL, Pech RP, Sweetapple PJ, Yockney I, Barron MC, Perry M, Nugent G, Carran R, Warne R, Brausch C, Duncan RP 2011. Unexpected consequences of control: competitive vs. predator release in a four-species assemblage of invasive mammals. Ecology Letters 14: 1035-1042.
Russell JC, Jones HP, Armstrong DP, Courchamp F, Kappes PJ, Seddon PJ, Oppel S, Rauzon MJ, Cowan PE, Rocamora G, Genovesi P, Bonnaud E, Keitt BS, Holmes ND, Tershy BR 2016. Importance of lethal control of invasive predators for island conservation. Conservation Biology 30: 670-672.

Sidorovich V, Solovej IA 2007. The stoat Mustela erminea population decline in northern Belarus and its consequences for weasels Mustela nivalis. New Zealand Journal of Zoology 34: 9-23.

Southland Times 1917. 9 June.

Sumption KJ, Flowerdew JR 1985. The ecological effects of the decline in rabbits (Oryctolagus cuniculus) due to myxomatosis. Mammal Review 15: 151-186.

Telegraphic News 1896. 26 November.

Tennyson AJD 2010. The origin and history of New Zealand's terrestrial vertebrates. New Zealand Journal of Ecology 34: 6-27.

Thames Star 1899. 2 November.

Thompson HV, King CM eds. 1994. The European rabbit: the history and biology of a successful colonizer. Oxford, Oxford University Press. 245 p.

Thomson GM 1922. The naturalisation of animals and plants in New Zealand. Cambridge. Cambridge University Press. $607 \mathrm{p}$.

Timaru Herald 1890. 25 September.

Tompkins DM, Veltman CJ 2006. Unexpected consequences of vertebrate pest control: predictions from a four-species community model. EcologicalApplications 16: 1050-1061.

Tuapeka Times 1906. 17 January.

Tuapeka Times 1909. 30 January.

Veale AJ, Clout MN, Holland OJ, Gleeson DM 2015. An invasive non-native mammal population conserves genetic diversity lost from its native range. Molecular Ecology 24: 2156-2163.

Waikato Argus 1909. 26 April.

Wairarapa Daily Times 1891a. 30 January.

Wairarapa Daily Times 1891b. 13 August.

Wairarapa Daily Times 1891c. 14 May.

Wairarapa Daily Times 1899. 28 August.

Wairarapa Standard 1884. 1 August.

Wanganui Herald 1903. 28 October.

Wells P 2009. The fall and fall in the legal status of mustelids in New Zealand. Environment and History 15: 343-368.

West Coast Times 1890. 18 June.

Whitehead AL, Edge KA, SmartAF, Hill GS, Willans MJ 2008. Large scale predator control improves the productivity of a rare New Zealand riverine duck. Biological Conservation 141: 2784-2794.

Wilmshurst JM, Anderson AJ, Higham TFG, Worthy TH 2008. Dating the late prehistoric dispersal of Polynesians to New Zealand using the commensal Pacific rat. Proceedings of the National Academy of Sciences USA 105: 7676-7680.

Wilson PR, Karl BJ, Toft RJ, Beggs JR, Taylor RH 1998. The role of introduced predators and competitors in the decline of kaka (Nestor meridionalis) populations in New Zealand. Biological Conservation 83: 175-185.

Winser H 1885. Te Awaiti Station Diary. Alexander Turnbull Library, Riddiford MS Papers 1392-22, Wellington.

Winser H 1886. Te Awaiti Station Diary. Alexander Turnbull Library, Riddiford MS Papers 1392-24, Wellington.

Woodville Examiner 1894. 23 April.

Editorial board member: Deb Wilson

Received 7 November 2016; accepted 20 March 2017 
Appendix 1. Approximate translation of handwritten records shown in Figures 2 and 3.

The names of farm hands and locations are uncertain, but show that the distribution process took several days, sometimes in very difficult conditions. The abbreviation 'do' was short for 'ditto', meaning 'as above'.

\section{Figure 2.}

17 Friday [July 1885] Fine.

Knox took 38 boxes stoats weasels to Toru Burton packed two boxes weasels to Pukeatua I packed two boxes to Knob $\&$ two to Brown Hill rocks went on \& saw Mrs Miller left pack horses at Toru \& came home

\section{Saturday Fine}

Burton packed 3 boxes weasels to Limestone Corner McRae do to Bugler...met Knox at ?Slack \& took four boxes weasels to Whare range Knox bringing remainder to homestead

19 Sunday Fine.

Burton McRae \& Berry packed four boxes stoats to [... Top ?Drunsfield \& self packed 4 boxes weasels to ?Sandy Hill \& brought teal from Ma... Gully

\section{Figure 3.}

28 Thursday [January 1886] Raining steadily

Scott Caverhill \& Johnny packed 6 boxes stoats \& weasels to Long Spur \& 4 do [ditto] to Blk Island Knox \& Drunsfield carted remainder down river Roderic \& self ...left 2 boxes Tutauram.... Hill 2 boxes stoats $\& 6$ do weasels $3^{\text {rd }}$ Blk Creek \&range 2 do whare range \& 2 do Limestone Hill 2 do head of creek in Slack

[In original diary, the distribution of boxes continued on 30th and 31 st January. The men returned to normal farming duties on 1st February] 